\title{
Design and construction recommendations for connections arrangement in anchored veneers with continuous air cavity
}

\section{Recomendaciones constructivas y de diseño para la distribución de las conexiones de la hoja exterior de un cerramiento con cámara de aire continua}

\author{
Ángeles Mas (Main Author) \\ Department of Architectural Constructions, Universitat Politècnica de València \\ Camino de Vera, s/n, 46022 Valencia (Spain) \\ amas@csa.upv.es
}

\section{Jose Vercher}

Department of Architectural Constructions, Universitat Politècnica de València Camino de Vera, s/n, 46022 Valencia (Spain)

jvercher@csa.upv.es

\section{Francisco Cubel}

Department of Architectural Constructions, Universitat Politècnica de València Camino de Vera, s/n, 46022 Valencia (Spain)

fracuar@csa.upv.es

\section{Enrique Gil}

Department of Structural Construction, Universitat Politècnica de València Camino de Vera, s/n, 46022 Valencia (Spain)

egil@upv.es

Carlos Lerma (Corresponding Author)

Department of Architectural Constructions, Universitat Politècnica de València Camino de Vera, s/n, 46022 Valencia (Spain)

clerma@csa.upv.es

Manuscript Code: 916

Date of Acceptance/Reception: 30.11.2017/01.06.2017

DOI: $10.7764 / R D L C .17 .1 .137$

\begin{abstract}
The optimization of connections arrangement to guarantee the anchored veneers with continuous air cavity stability is necessary, for better performance and durability of the façade. In this paper, different arrangements for the anchors to structure and different kinds of inner leaf are proposed, with the aim of selecting the best for the behavior of the façade against wind actions in cases of residential buildings. A very significant increase in stiffness is observed simply placing the anchors to the structure alternately to one side and the other of the structural element, and it is still more when there are wall ties between leaves, especially to a brickwork inner leaf.
\end{abstract}

Key words: brickwork, masonry, wall ties, self-supporting wall, restraint connections.

\section{Resumen}

La optimización de la disposición de las conexiones es necesaria para garantizar la estabilidad de la hoja exterior de un cerramiento con cámara de aire continua, para un mejor funcionamiento y durabilidad de la fachada. En este trabajo se proponen diferentes disposiciones para los anclajes a la estructura y diferentes tipos de hoja interior, con el objetivo de seleccionar el mejor para el comportamiento de la fachada frente a las acciones del viento en los casos de edificios de viviendas. Un aumento muy significativo de la rigidez se observa simplemente colocando los anclajes a la estructura alternadamente a un lado y al otro del elemento estructural, y aún más cuando hay llaves entre las hojas del cerramiento, especialmente a una hoja interior de ladrillo.

Palabras clave: obra de fábrica, mampostería, Ilaves entre hojas, muro autoportante, conexiones de fijación.

\section{Introduction}

The facebrick façade is a type of envelope widely used in residential buildings today. The origin of this kind of façades are the bearing walls widely used in traditional architecture. With the appearance of the framed structures, the façades lost their load-bearing function but the brick continued in use for its aesthetic quality, its ease of construction and easy 
maintenance. Instead, the requirements of the standards are continuously increasing, among which nowadays are buildings without cracking, without water ingress and consume little energy.

Most common way to build these enclosures is using a multilayer façade which is a traditional brick wall. It consists of a perforated brick outer leaf that rests partially on the slabs, protruding $4 \mathrm{~cm}$ to cover the front of them, an air cavity, a thermal insulation and a hollow brick inner leaf.

The ceramic pieces that cover the slabs have problems of detachment in this traditional typology (Del Coz, J.J., Lozano, A., Adam, J.M., Martín, A., 2011; Da Silva \& Mendes, 2007). There is not a single analytical method to calculate the loadbearing capacity of unreinforced brick masonry walls. This depends on the geometric configuration and the type of wall test (Bernat-Maso, Gil \& Roca, 2014). A realistic description of the behavior is essential to accurately predict the loadbearing capacity of this type of walls, especially when the failure mode is primarily second-order bending (Bernat, Gil, Roca, Sandoval, 2013). Thermal bridges and waterproofing problems in the façade-slab connection are also detected when the outer leaf is interrupted (Del Río, 2008).

The self-supporting façade has meant a change in the construction of the façades. Its own definition overcomes the problems of sealing, insulation and waterproofing of conventional enclosure (Paricio, 1995). Connection elements are necessary to connect the outer leaf with the building structure to ensure the stability of this leaf of the self-supporting façade. The horizontal loads are transmitted to the supporting structure using these anchors. The supported vertical loads are only due to the self-weight of the outer leaf. These loads are transmitted to foundations via the outer leaf. The ground floor is the most compressed stretch.

The constructive process of the two types of enclosures used in Spain is different, traditional brick wall in which both leaves rest on slabs and self-supporting wall where only the inner leaf rests on the slabs. The outer leaf of the enclosure is executed first in the conventional façade, supporting it on the slabs and reaching the pillars. Once constructed the outer leaf, the inner leaf rises at the same time that the thermal insulation is placed. In the self-supporting façade, first the inner leaf is built, leaving the connection ties to the outer leaf prepared. Then the thermal insulation is placed on the inner leaf, passing in front of slabs and pillars. Finally, the outer leaf is constructed by passing continuously in front of the structure. The outer leaf is separated from the insulation leaving an air cavity that improves the waterproofing of the façade. The self-supporting façade solves the thermal bridge that exists in the conventional façade.

The self-supporting façade has been studied and tested from the viewpoint of waterproofing (Dudas \& Terjek, 2015) and heat insulation (Alghamdi \& Alharthi, 2017; Hamid \& Wallentén, 2017). However, it has not been studied in detail from the viewpoint of stability and strength (Silva, Lourenço \& Milani, 2017). This paper is a continuation of the research work for brick enclosures recommendations with continuous air cavity (Cubel, Vercher, Mas, Gil, 2012), where the authors studied the resistant behavior of the self-supporting façade, including design improvements. This study defined a construction recommendations based on a valid analytical model to study the mechanical behavior of masonry. Current research focuses on the study of needed connections in the outer leaf of this type of façade.

Horizontal loads (wind and earthquake actions) in anchored veneers are transmitted to the supporting structure through the connections. There is a great amount of studies about the behavior of brick veneer walls under seismic actions (Martins, Vasconcelos \& Campos, 2017), but not related to wind pressure. This work has focused on the influence of these connections against wind load.

\section{Connection elements}

The self-supporting wall starts with a sufficiently rigid element and have connections to the building structure. Two types of connections used in the execution of this façade can be distinguished (Figure 1a). The first ones are the anchors that link the outer leaf with the building structure. This may be a framed structure or a load bearing walls structure. The second ones are the wall ties that connect the outer with the inner leaf in the multilayer enclosures.

The collapse of masonry walls is mostly due to out-of-plane actions (Zuccarello, Milani, Olivito, Tralli, 2009; Silva, Lourenço \& Milani, 2017), as wind or earthquake. Anchors between the outer leaf and the structure should support the outer leaf against the horizontal actions and should allow the free expansion of the outer leaf with respect to the building structure. The pathology associated with changes in temperature (Mas, Galvañ \& Gil, 2009) or the moisture expansion of the ceramics (Gordejuela, 2003) are avoided if the outer leaf can move independently of the structure. Likewise, enforcement tolerances allow resolving possible structural imperfections. 
Figure 1. a) Geometry of an anchored veneer with continuous air cavity. b) Connection of the outer leaf with pillars and slabs. (Left) Profile embedded in the concrete; (central) Bolted anchor; (right) Anchor bolted laterally. Self-Elaboration.

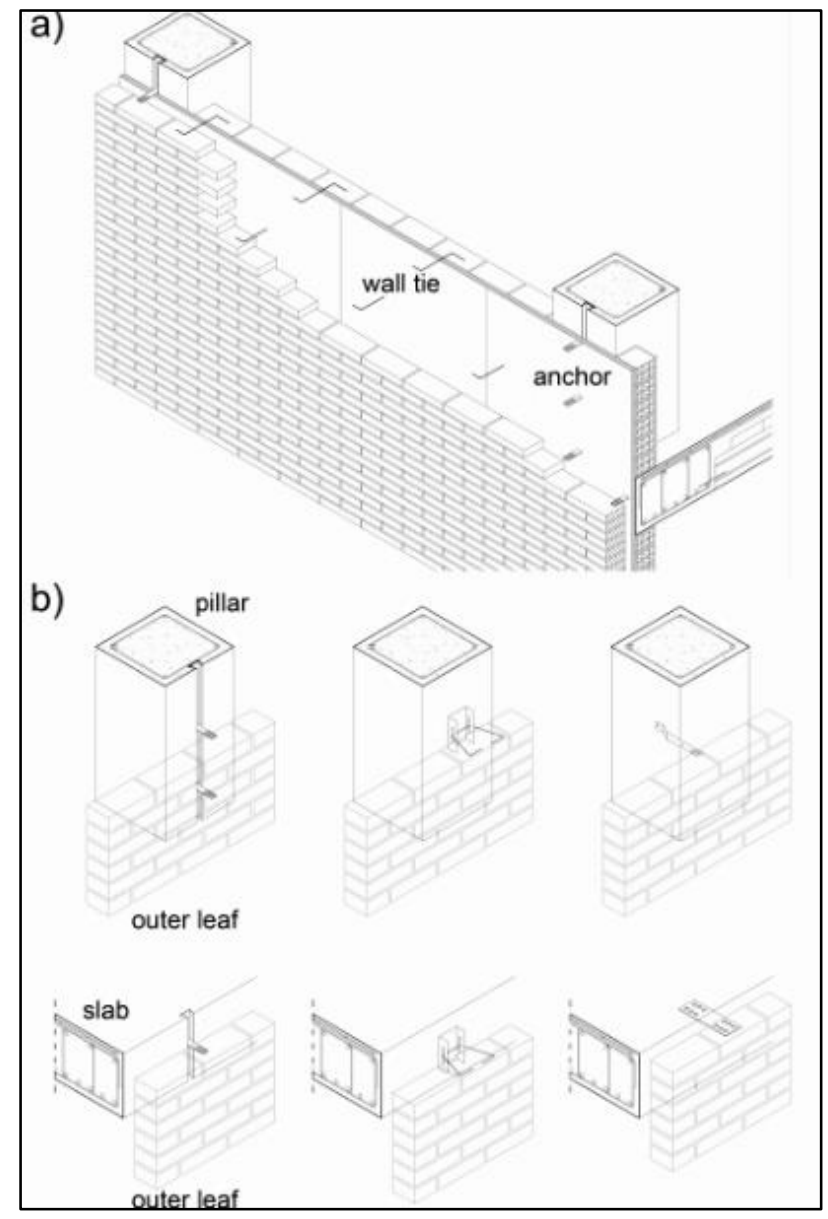

These anchors are attached to a stiffening upright element, pillars or structural walls, and to a stiffening horizontal element (slabs). Figure $1 \mathrm{~b}$ shows different types of connections to pillars and slabs. These anchors may be embedded in the concrete or bolted subsequently. The connections analyzed in this work do not allow the transmission of vertical forces, due to their possibility of movement or low stiffness. Therefore, all vertical loads of the outer leaf are transmitted to the ground.

The distribution and number of connections have influence in the behavior of the outer leaf. Against a wind pressure, the areas around them have tensile on the outside of the brickwork and compressions on the inner side. The areas distant from these connections have compressions in the outer side and tensile in the inner, acting the same effort. In the case of wind pressure, the connections may buckle because they work in compression. If they are sized for pressure, they amply fulfilled to suction due to they are working in tension and the buckling cannot appear.

In the two leaves enclosures, wall ties can also be used between the leaves and help in supporting the perpendicular actions. These ties may have a dripcap to avoid waterproofing problems because of the ties between leaves. In this way, the dripcap prevents that the ties is an entry point of water. Another added feature that these ties can play is to be the support of the thermal insulation. The insulation panels are attached by means of fixing rosettes. The location of the wall ties prevents subsequent maintenance is needed. In addition, the air cavity can be found with high humidity situations, so the stainless steel ties are recommend (Adell, 1996).

\section{Current standards criteria}

Anchors that connect the outer leaf to the structure are essential to ensure stability against horizontal forces. The Spanish standards of enclosures do not define a minimum number of these connections. The Berstein's studies (Berstein, Champetier \& Peiffer, 1985) propose the placement of anchors to the pillars each $40 \mathrm{~cm}$ and anchors to the slabs each $60 \mathrm{~cm}$. 
The Spanish code, Código Técnico de la Edificación (CTE) (Ministerio de Fomento, 2006), does not provide information in terms of the amount or geometry of wall ties between leaves. According to CTE, the number of ties must be equal to the calculation value of lateral action per unit area divided by the calculation resistance to compression or tensile of the tie.

The British BS-5628 standard (2005) adds the required conditions for wall ties between the two leaves in anchored veneers. The amount of these connections is set to 2.5 ties per square meter in enclosures whose two leaves have a thickness greater than $90 \mathrm{~mm}$ and 4.9 ties per square meter in façades with leaves with thickness less than $90 \mathrm{~mm}$. The wall ties should be evenly distributed over the wall surface except around the openings, and preferably in a staggered pattern. In the vertical edges of the openings and in the edges of the movement joints, additional ties are placed every $30 \mathrm{~cm}$ placed at $22.5 \mathrm{~cm}$ from the edge as a maximum. Wall ties must be introduced into the mortar at least $50 \mathrm{~cm}$ on each leaf of the enclosure.

The number of wall ties in the enclosure is also considered in French standard 'Unifié Document Technique' (UDT) (1990). In this case, the UDT establish that ties each $60 \mathrm{~cm}$ placed staggered in alternate rows must link the two leaves of the enclosure.

The Eurocode 6 (European Committee for Standardization, 1992) recommends the incorporation of ties in the anchored veneers and in the double walls with at least two ties per square meter. Ties are placed with a maximum horizontal spacing of $90 \mathrm{~cm}$, and the maximum height distance between rows should not exceed $60 \mathrm{~cm}$. Ties are placed in a staggered pattern in alternate rows. This study focuses on the advantages of the geometry and arrangement of the anchors for the outer leaf behavior.

\section{Materials and method. Numerical simulation}

The analysis of the behavior of the proposed enclosure is performed by the finite element method. Ansys is the employed software to obtain the stresses, displacements and crack pattern of the façade. All types of nonlinearities, yielding and fracture are taken into account in this finite element software.

The façade can be modelled in different approach levels. Micro-modelling, where bricks and mortar are modelled as independent elements, is suitable to simulate the behavior of detailed or small parts of the brickwork. Macro-modelling, a general continuous model, is suitable to study the brickwork compound (López, Oller \& Oñate, 1998). Enclosure simulation is performed using a macro modelling. To characterize this type of modelling is necessary to know the mechanical properties of the masonry as a whole, not just brick and mortar. The simulations of this research have used the Solid 65 element for assessing the brickwork behavior. A mesh with an element size similar to a brick has been used, since macro-modelling has been chosen to study the general behavior of the façade.

The behavior of the brickwork and its modelling has been studied in depth in recent years (Brencic \& Felice, 2009; Dilrukshi, Dias \& Rajapakse, 2010). The values that define the behavior of the evaluated masonry are included in Table 1. The authors of this research have tested and successfully used this model to strengthen the self-supporting wall.

Table 1. Material properties. Self-Elaboration.

\begin{tabular}{|c|c|c|c|c|c|c|}
\hline & \multirow[b]{2}{*}{ Density } & \multirow[b]{2}{*}{$\begin{array}{c}\text { Elastic } \\
\text { Modulus }\end{array}$} & \multirow[b]{2}{*}{ Poisson's Ratio } & \multicolumn{2}{|c|}{ Shear transfer coefficient } & \multirow{2}{*}{$\begin{array}{l}\text { Uniaxial } \\
\text { Tensile } \\
\text { Strength }\end{array}$} \\
\hline & & & & $\begin{array}{l}\text { Open } \\
\text { crack }\end{array}$ & Closed crack & \\
\hline Masonry & $18 \mathrm{kN} / \mathrm{m}^{3}$ & $2 \mathrm{GPa}$ & 0.2 & 0.25 & 0.6 & $0.3 \mathrm{MPa}$ \\
\hline
\end{tabular}

The employed model has been widely used in research and its behavior has been proven (Dilrukshi, Dias \& Rajapakse, 2010; Zhu, Zhu \& Yang, 2011; Vercher, Gil, Mas, Lerma, 2015). However, before applying the macro modelling to the enclosure, it has been shown that the results coincide with the results of experimental tests. The used test to validate the results against vertical forces is the Page's study (Page, 1978), which has served to other authors to check their models, as Lourenço (1996) and Lopez (López, Oller \& Oñate, 1998). Figure 2a shows the Page's tested model geometry. The modelling is done by dividing the wall in finite elements to match the load application points and supports. The wall thickness is divided into five finite elements.

Page's test consists of applying a vertical load of $20 \mathrm{kN}, 40 \mathrm{kN}$ and $60 \mathrm{kN}$ over a masonry on two supports and measure the stresses on the vertical axis, Y-axis. The stress state in the brickwork when these loads are applied has been obtained 
in order to check the validity of this model. Moreover, cracking is obtained and a graph of the vertical stress at medium height of the wall is performed. These values are compared with the measured stresses by Page (1978) and the calculated values by Lourenço (1996), obtaining a great accordance.

Figure 2a shows the stress state of the wall due to the load of $60 \mathrm{kN}$, as an example. In some places, even the model used in this research is closer to experimental results than those obtained in other studies. The model takes into account the cracking of the masonry, which was not taken into account in other homogenate models.

Gutierrez's tests (2008) are simulated with finite element in order to validate the model against horizontal forces. Gutiérrez tests a specimen of $3 \mathrm{~m}$ high and $5 \mathrm{~m}$ wide, built with a wall $12 \mathrm{~cm}$ thick. The wall is supported vertically at the bottom. Respect to horizontal forces the wall is two-hinged and the side edges are free. Subsequently, it is loaded horizontally with two load lines, one at $0.75 \mathrm{~m}$ height and $2.25 \mathrm{~m}$ another. This horizontal load is increased until failure of the wall. The collapse occurs at the load line located at $2.25 \mathrm{~m}$ because in this point there is insufficient self-weight as to center the horizontal load.

This test has been simulated using finite elements. Figure $2 \mathrm{~b}$ shows the test geometry and the comparison between the test results and our simulation. The resulting graph shows a linear behavior of the wall until a horizontal load of $18 \mathrm{kN}$. The slope changes at this point and displacements greatly increased without increase charge. From here the material is cracked and its behavior is nonlinear. The graph obtained in the test matches significantly with the graph obtained in our modeling. Due to this, the simulation of the behavior with vertical and horizontal stresses is considered valid.

In this research, cases have been validated with parallel and perpendicular stresses to the plane, which correctly represent the anisotropy of the material in the simulations. Therefore, the derived results are accepted as valid.

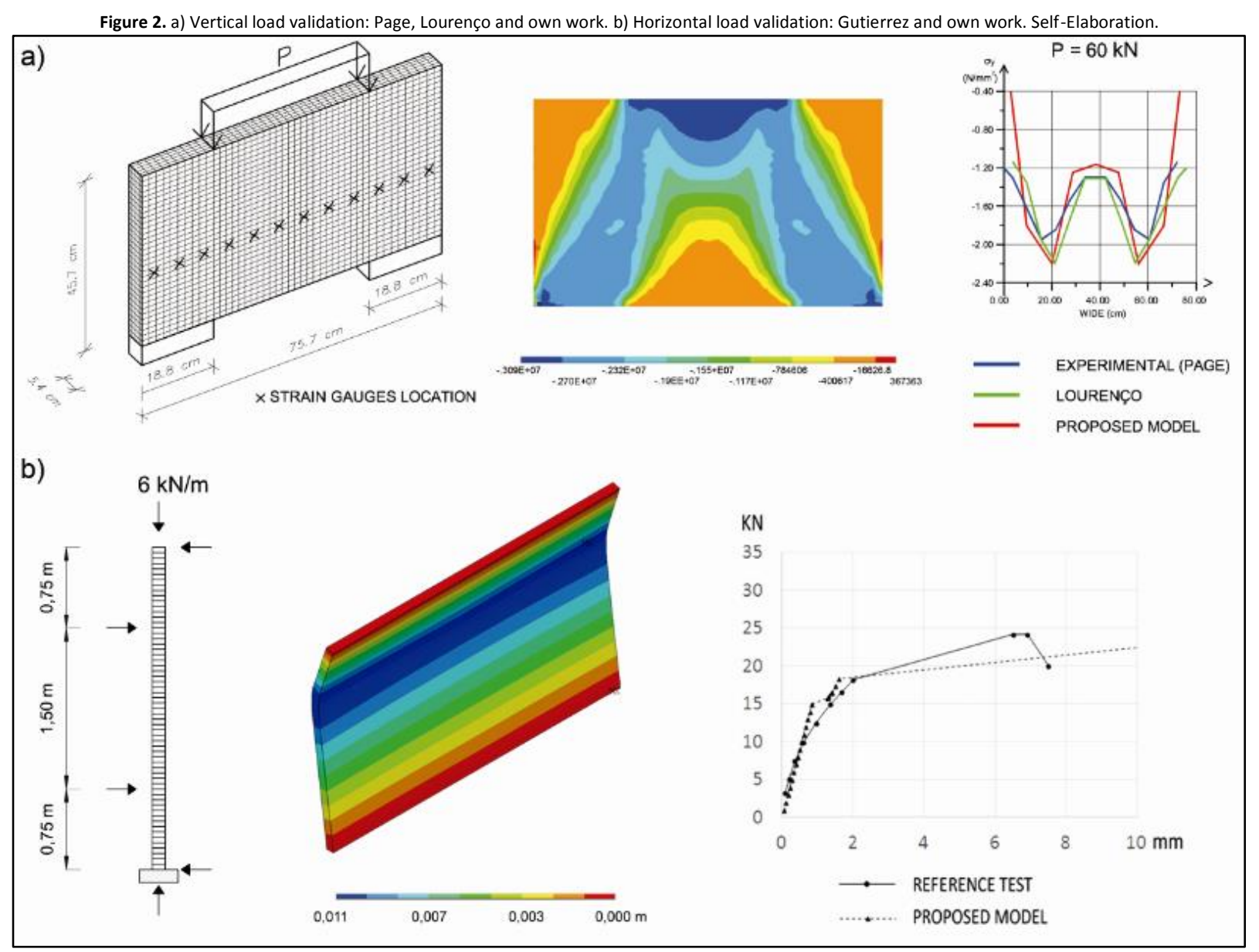




\section{Anchors to building structure: Geometry, strain and cracking}

A façade of a four-story building with self-supporting wall is taken as basis for this work. The clearance between slabs $(2.7 \mathrm{~m})$ and the distance between pillars $(4.4 \mathrm{~m})$ is the usual in residential buildings in Spain. These dimensions allow observing the influence of the disposition of the anchors to the structure.

The façade is modeled supported on a rigid element (foundation or concrete wall) with blocked rotation. This aspect has been studied in depth in other works (Pena, Calavera \& Llorens). The anchors are modeled as linear steel elements with $4 \mathrm{~mm}$ diameter that connect the exterior leaf with an element which its movements impeded. The building top has a free edge. The simulated façade has horizontal continuity, so that the displacement in the x-axis of the lateral edges is impeded.

Four different models were studied to check the influence of the disposition of the anchors. Model 1, without openings, is a blind wall from the foundation to the top of the building. The exterior leaf has anchors that fix it to the slabs and pillars. Model 2 is a self-supporting wall with openings. The size of the openings is greater than $10 \%$ of the total size of the wall (Ministerio de Fomento, 2006). The disposition of the anchors is the same in Model 1 and Model 2, which is the common configuration performance. Model 3 is a variant of the Model 2 in which the anchors move alternately at the upper and lower face of the slab. Model 4 is another variant of Model 2 placing alternately the connection anchors also on the pillars. The anchors screwed into the sides of the pillar allow this disposition. Figure 3 shows the geometry of the four models.

Figure 3. Anchors to the building structure. Geometry of the models. Self-Elaboration.

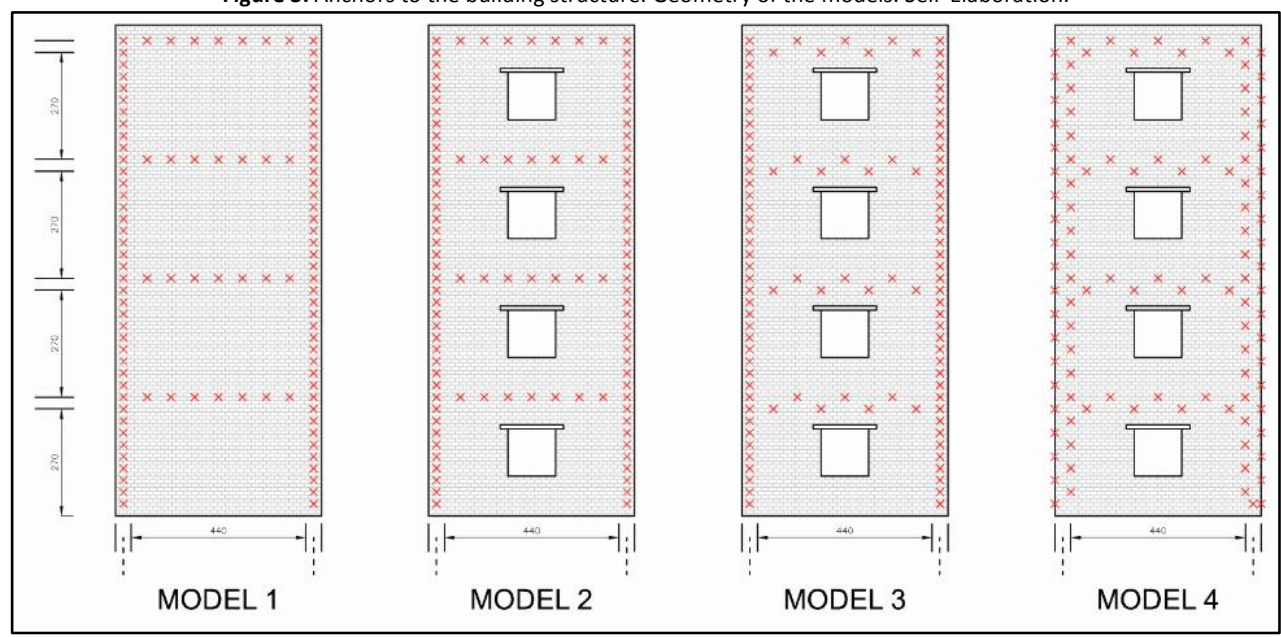

The four studied models were loaded with the weight of the brick leaf and a wind action of $4,000 \mathrm{~N} / \mathrm{m}^{2}$. This load is higher than standard wind load (Ministerio de Fomento, 2006), of the order of $800 \mathrm{~N} / \mathrm{m}^{2}$. The aim of this research is to load until collapse in order to know the behavior in the entire load range. The weight of the wall is introduced in a first load step. The horizontal load is introduced in a second load step and increases gradually. The self-weight has been applied first because it is always present, and the wind load has been added in a second load step because it appears occasionally, with all the self-weight applied.

A stretch is the façade area corresponding to a story. In all four models, the stretch with a larger displacement is the corresponding to the top floor, mainly due to two reasons. First, in this situation the stretch has not continuity upward to counteract the positive bending of this stretch. Furthermore, this stretch has the same wind load than the others, but it has lower self-weight. The cracking is also higher in the top floor stretch.

The results obtained in these models show the beneficial effect of the self-weight of the outer leaf. It can be seen in Figure 4. The largest displacements appear at the point located on the third floor. As the vertical load increases, the displacements are smaller. In fact, displacements are reduced on the second floor, and the lowest displacements are produced in the wall in the ground floor. The masonry has a better performance against horizontal loads when the vertical load is increased. Self-weight improves this resistance in self-supporting walls, since they do not receive more vertical loads. 
Figure 4 shows the displacement of the outer leaf in the direction perpendicular to the façade. It also shows the state of cracking for loads higher than wind load. Displacement graphs show a better performance in the Model 1, without openings, than in the models with openings. The displacements of Model 2 are higher than in Model 1 . Models 3 and 4 have lower displacements, representing an improvement of behavior. The variation introduced in the disposition of connections of the Model 3 improves linear support in slabs, increasing the tensile surface on the outside. Of the four analyzed models, the Model 4 has less displacement when the horizontal load is applied. In Model 4 , the disposition of anchors to pillars reduces the clearance distance between the anchors and therefore the horizontal deflection of the wall.

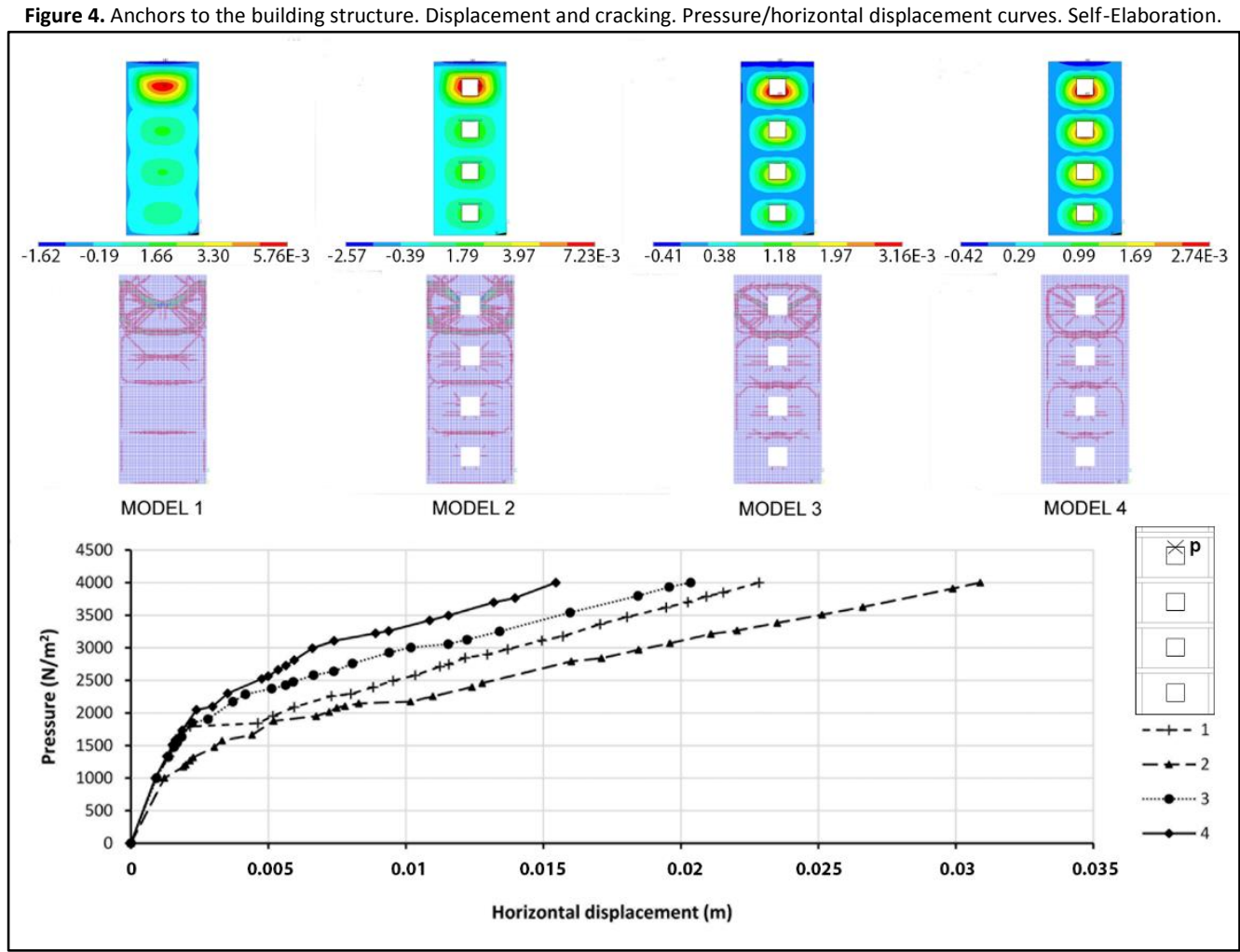

Cracking analysis of the enclosure has been made, in parallel with the study of the displacement. Cracks appear when the tensile strength of the brickwork is surpassed. Ansys software has an option for studying the cracking of the elements. The user can see the evolution of the cracking as the load increases. The first cracks appear around the connection anchors to the building structure. In all models, the stretch of the top floor has more cracking. This stretch has also the greater deflections. In Model 1, the cracks appear from the corners to the center of the stretch. Models 2 , 3 and 4 show cracks from the corners of the openings and horizontal cracks, which originate at the jambs. The Model 3 has a lower crack level than Model 2, which shows the beneficial effect of the location of the anchors to slabs. The cracking is reduced in the contour of the slabs and pillars. Cracking at the center of the stretches is also reduced in Model 3. Model 4 shows less cracking than previous, evidencing the effectiveness of the measure of the use of staggered toggle anchors also on pillars. Cracking on the top façade has also been reduced in Models 3 and 4.

Figure 4 shows the displacement of one point of the enclosure with respect to the applied load on the four studied models. The chosen point where displacements are measured is the midpoint of the jamb of the top floor opening. This point is chosen because it is the area with the greatest deflection.

Model 1, without openings, has a branch in which there is proportionality between stress and strain. With a load of $1,600 \mathrm{~N} / \mathrm{m}^{2}$ a step is produced, after which the wall will distort more severely. In addition, a change of slope is produced, due to cracking appeared in the walls. Model 1 has a smaller displacement than Model 2, in which there are openings. In Model 2, the change is produced at a load value of $1,000 \mathrm{~N} / \mathrm{m}^{2}$, less than in the Model 1 . Displacements in Model 2 are always higher than in Model 1, due to the effect of the openings.

The displacements are lower in Model 3 and Model 4 than in Model 1 and Model 2. In models 3 and 4, the behavior with openings is better than in the model without openings. For the same load, displacement is smaller in Models 3 and 4 than in Model 1. Comparing Models 3 and 4, the beneficial effect of the modification of the anchors to the pillars is 
checked. Model 4 is the model with lower displacement. The displacement in Model 4 is half that in Model 2 at the maximum load of $4,000 \mathrm{~N} / \mathrm{m}^{2}$.

\section{Wall ties: Geometry, strain and cracking}

The connection ties between leaves, also known as wall ties, are studied at this point. Four blind enclosure models are compared in order to assess the effect of the type of inner leaf. The outer leaf is only connected to the structure with anchors in the Model A, due to this model has not inner leaf. This model is compared with an enclosure of two brick leaves attached with ties, with three variations.

On two leaves façades, the inner leaf is built on slabs and therefore transmits the vertical load to the slabs. The pillars are the support of this leaf against horizontal forces. The outer leaf runs in front of the slabs and fixed with anchors to the structure and wall ties to the inner leaf. Therefore, the boundary conditions of the inner leaf are embedded in all edges. And the boundary conditions to the exterior leaf are embedded in the encounter with the ground and horizontal movement is prevented in each of the connection anchors to the structure. The wall ties are modeled as a steel rod of $4 \mathrm{~mm}$ thick.

In Model B, the inner leaf is constructed with hollow brick laid in shiner bond pattern. The inner leaf has a thickness of $7 \mathrm{~cm}$. In Model C, the inner leaf is built with hollow brick laid in stretcher bond pattern. The inner leaf has a thickness of $12 \mathrm{~cm}$. In these models, the density of the hollow brick is $12 \mathrm{kN} / \mathrm{m}^{3}$. Table 1 shows other ceramic properties. In addition, in Model $D$ the inner leaf is constructed with plasterboard panels fixed to a metal substructure. The substructure is composed of $U$-shaped metallic profiles placed every $60 \mathrm{~cm}$, with an area of $1.52 \mathrm{~mm}^{2}$. Mechanical characteristics are density $78.5 \mathrm{kN} / \mathrm{m}^{3}$, elastic modulus $2 \cdot 10^{2} \mathrm{GPa}$, Poisson's Ratio 0.3 , yield stress $500 \mathrm{MPa}$ and tangent modulus $3 \mathrm{GPa}$ (Vercher, 2013). Figure 5 shows the geometry of the studied models. The wall ties for interconnecting masonry are placed every $60 \mathrm{~cm}$ in staggered rows, following the standards recommendations. A steel bar of $4 \mathrm{~mm}$ of diameter is used as a tie between leaves.

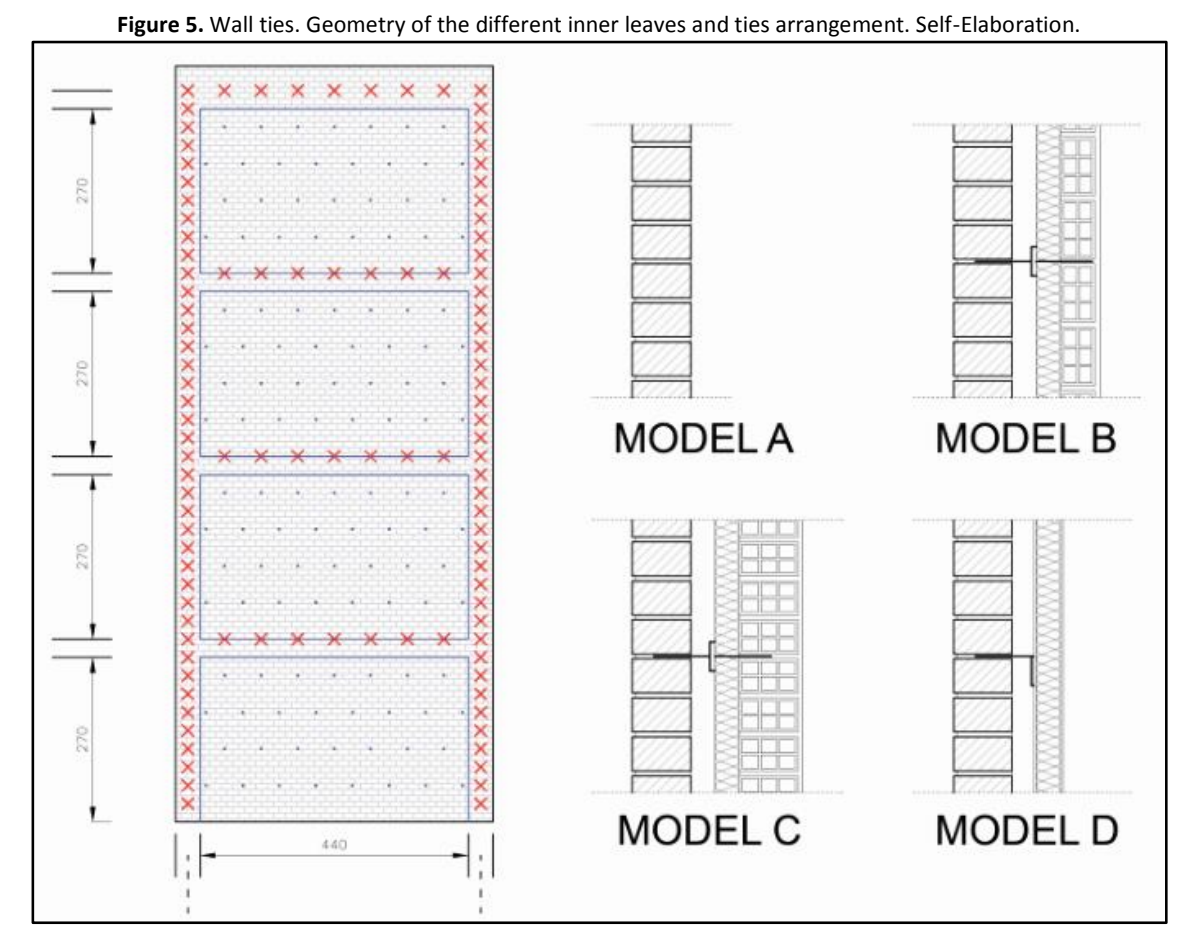

The stiffness of the inner leaf, typically formed from a hollow brick $7 \mathrm{~cm}$ thick, is smaller than the outer leaf and the resistance increased is not large. If the inner leaf thickness increases, the stiffness rapidly enhances. The thickness of the inner leaf can be increased simply by placing the bricks with stretcher bond pattern. Thus, the brickwork pattern of the exterior and interior leaf is the same, so that the placement of the ties is simple without need to place height adjustable ties.

The self-supporting wall is connected with anchors to columns and slabs. The distance between pillars is $4.40 \mathrm{~m}$ and the clearance between slabs is $2.70 \mathrm{~m}$. The slabs and pillars support the inner leaf, and the outer leaf passes separated of the structure. Self-weight acts on the two leaves and the wind load acts only on the outer leaf. 
Presence of holes on brick enclosures affect more than the arrangement of connections. Therefore, in this part blind panels of façades have been analysed. The influence of holes on brick enclosures with continuous air cavity will be studied in future works.

In Model A, the maximum stress values are located in the area of anchors to structure and at the center span. With the inclusion of ties between leaves appears a decrease of the maximum stresses with a homogenization of values in the wall. The stresses at the connections are reduced in value and in area of influence. The value of the stress in the center span was also significantly reduced.

The horizontal displacement and cracking of the models are shown in Figure 6. Models with ties to the inner leaf of brick, Models B and C, have lower displacements that model A. Model C with inner brick leaf with stretcher bond pattern has lower displacements than model B. Model D improves the performance of the initial model but less so than models with masonry inner leaf. The displacement in Models B, C and D for all stories are more homogeneous than in Model A.

The cracking pattern of the Model A is the same as that observed in 'Anchors to building structure: Geometry, strain and cracking' section. The break lines start at the vertices and move at an angle of $45^{\circ}$ to be connected in a horizontal line. As the load increases, parallel cracks appear until the entire wall is cracked. Model B, with ties to a brick leaf of 7 $\mathrm{cm}$ thick, reduces cracking regarding Model A. Cracks appear with a greater load and appear a much lesser extent. Cracks appear in the junction between the inner leaf and the building structure. In Model C, cracking is further reduced. The cracks inclined at $45^{\circ}$ disappear completely. Cracking appears in line with the structure. When the stiffness of the inner leaf is increased, cracking in the self-supporting enclosure is similar to an enclosure supported in the structure. Model $D$ has a better performance than Model $A$ but worse than the Models $C$ and $D$, because the metal studs have a lower stiffness than masonry inner leaf.

Figure 6 includes a comparison between the displacements at the central point of the upper story for the four models. It clearly shows the enhancement by inclusion of the connections. The model with the inner leaf laid in stretcher bond pattern is the best mechanical performance has, and allows placing wall ties interconnecting masonry easily. By increasing the thickness of the inner leaf also improves the thermal insulation of the façade.

Figure 6. Wall ties. Displacement and cracking. Pressure/horizontal displacement curves. Self-Elaboration.

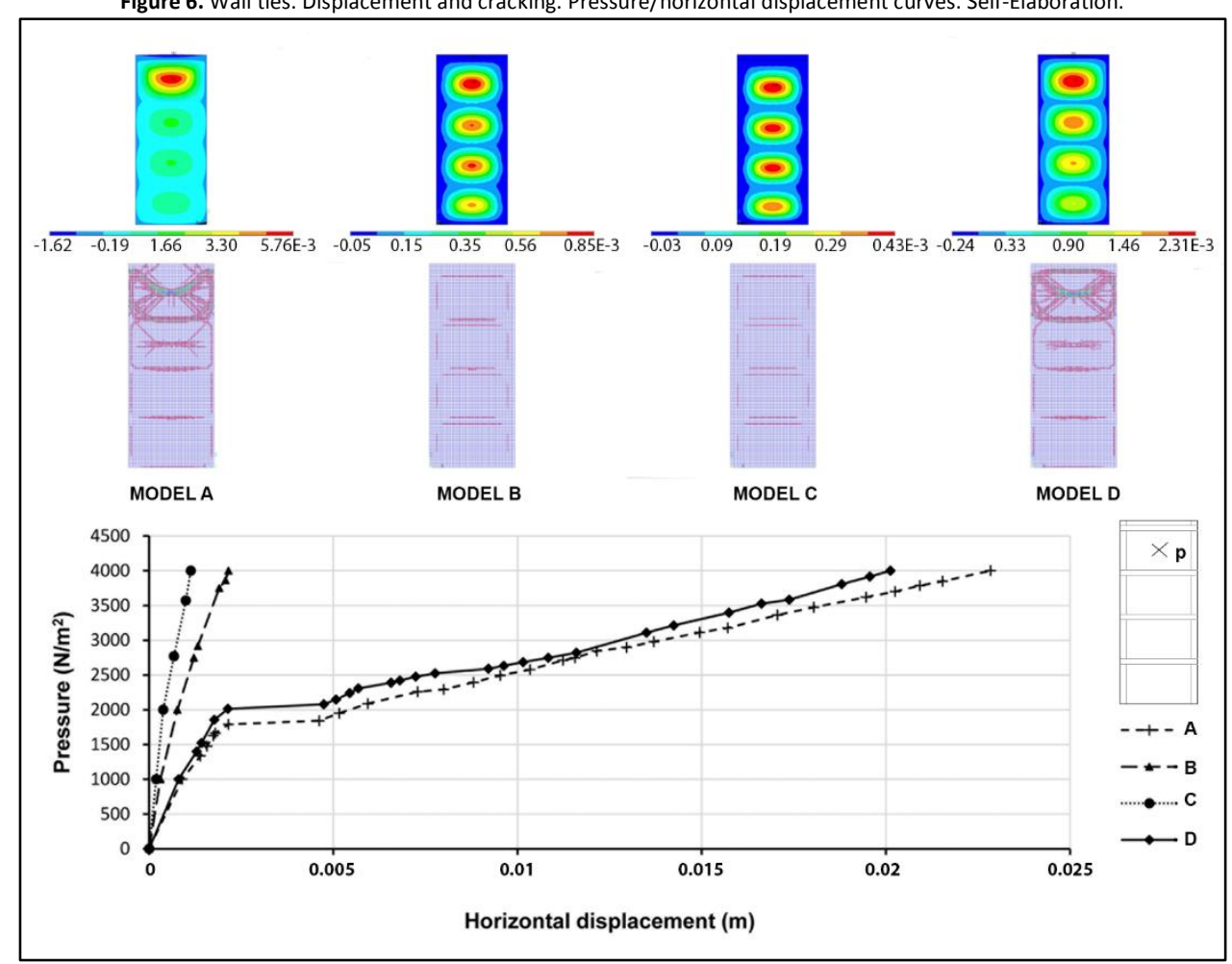


A self-supporting brick wall is designed with anchors connecting the outer leaf to slabs and pillars and wall ties between leaves. In view of the results, it is recommended to distribute the anchors to slabs placed every $60 \mathrm{~cm}$ in horizontal and the anchors to pillars placed every $30 \mathrm{~cm}$ vertically, both arranged alternately. Regarding the ties between leaves, they are placed every $60 \mathrm{~cm}$ in staggered rows. The solution was made with brick inner leaf and inner leaf constructed with plasterboard panels fixed to a metal substructure.

Figure 7a shows the construction criteria for the case of $12 \mathrm{~cm}$ thick brick interior leaf. The plan view includes two rows of brick, to show the alternation of the ties. The same brick distribution in the inner and outer leaf is shown in the section view, allowing using a steel rod Z shaped as a tie. These ties are placed embedded in the mortar joints. Anchors to slabs are placed at the bottom face level and the next anchor at the upper face level of the slab. In pillars, bolted anchors are also used alternatively displaced. The elevation shows the disposition of all used anchors.

In the case of plasterboard panels, wall ties cannot be placed in staggered rows. In this case, ties are placed every $60 \mathrm{~cm}$ both vertically and horizontally (Figure $7 \mathrm{~b}$ ). The ties used between leaves are screwed to metal studs and placed in mortar joint of the outer leaf. Anchors to the structure are arranged like in the previous case.

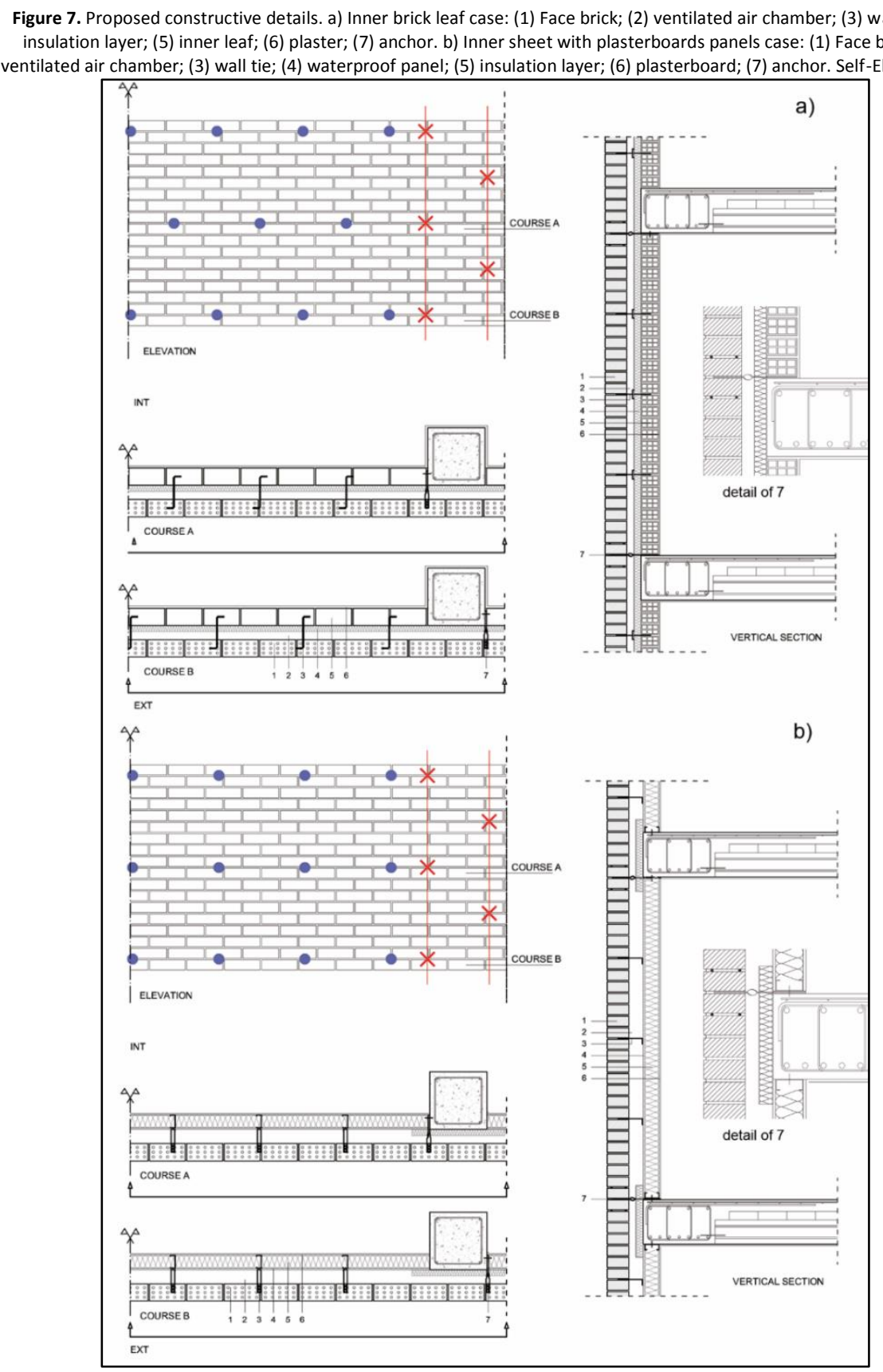


The details also include reinforcement rods in horizontal joints to reduce the cracking in the support zones (Cubel et al., 2012). The enclosure in addition to meeting the stability requirement must meet the conditions of waterproofing and thermal insulation. Therefore, the design includes a ventilated air cavity to prevent water entry problems, with waterproofing membrane when the air cavity is interrupted. The rigid board insulation covers the building structure to avoid thermal bridges in each case. It must be fitted to the contour of the holes similarly.

The anchored veneer with continuous air cavity is a type of façade that allows a clear solution for the requirements for a brick façade: stability, insulation and waterproofing. This façade is supported on foundations and passes in front of the building structure creating a continuous air cavity between the external wall and the structure.

The self-supporting wall requires anchors and wall ties to give stability to the efforts perpendicular to its plane. The outer leaf behaves like a plane that transmits the stresses to the anchors by bidirectional bending. To optimize the wall ties arrangement that guarantees stability is necessary, due to the high cost of their placement.

In this paper, different arrangements for the anchors to structure and different kinds of inner leaf are proposed, with the aim of improving the behavior of the façades against wind actions.

- $\quad$ Self-weight is decisive against horizontal loads on self-supporting walls. The case of a blind four-story building has been studied. The vertical load increases on the lower floors. The displacements and cracking in the ground floor are lower than those in the upper floors are. On the upper floor, a surface load of $1,826 \mathrm{~N} / \mathrm{m}^{2}$ is necessary to achieve a horizontal displacement of $4 \mathrm{~mm}$. The load required to achieve this displacement increases in the lower floors. On the ground floor, this increase may reach values of $119 \%$ from the upper floor, which is more than double the load.

- The most widespread standards propose to use anchors to the pillars at a maximum distance of $40 \mathrm{~cm}$ vertically and to the slabs every $60 \mathrm{~cm}$ horizontally. Anchors in pillars and slabs form lines where the stresses are accumulated, and thus cracking appears.

- A very significant increase in stiffness is observed, with the same number of anchors, by simply placing them alternately to one side and the other of the structural element, increasing the degree of embedding. Proposed arrangement of the anchors reduces stresses concentrations at the supports, reduces horizontal displacements and reduces the cracking of the masonry. If anchors are placed staggered in slabs, the façade can load up to $37 \%$ more than aligned anchors model. In the case of staggered anchors in slabs and pillars, the strength increases up to $52 \%$ over than aligned anchors model.

- With regard to existence of wall ties between leaves, in addition to anchors to the structure, the stiffness increases with the stiffness of the inner leaf. Stiffness increases slightly up to $12 \%$ when a plasterboard panel performs the inner leaf, and very significantly, when the inner leaf is brickwork, being $124 \%$ better in the case of vertical disposition of double-hollow brick.

- The wall with the 11-cm thick inner leaf, with stretcher bond pattern, is which present less deformation and cracking. In addition, this inner leaf facilitates the building of the enclosure because the rows of the inner and the outer leaf are matched.

Significant improvements in the behavior of the façade with the same number of connections has been achieved with this work. Constructive criteria have been detailed with specific solutions for use them with the proposed arrangement.

Adell, JM. (1996). La fábrica armada y la fachada contemporánea. Nueva Arquitectura, 4, 53-80.

Alghamdi, A.A., Alharthi. H.A. (2017). Multiscale 3D finite-element modelling of the thermal conductivity of clay brick walls. Construction and Building Materials 157, 1-9. https://doi.org/10.1016/j.conbuildmat.2017.09.081

Bernat, E., Gil, LI., Roca, P., Sandoval, C. (2013). Experimental and numerical analysis of bending-buckling mixed failure of brickwork walls. Construction and Building Materials, 43, 1-13. http://dx.doi.org/10.1016/j.conbuildmat.2013.01.025

Bernat-Maso, E., Gil, LI., Roca, P. (2014). Analytical method for the assessment of unreinforced brick masonry walls subjected to eccentric compressive loads. Construction and Building Materials 73, 180-186. http://dx.doi.org/10.1016/j.conbuildmat.2014.09.105 
Berstein, D., Champetier, J., Peiffer, F. (1985). El muro de dos hojas en la arquitectura de hoy. Barcelona: Gustavo Gili.

Brencic, A., Felice, G. (2009). Brickwork under eccentric compression: experimental result and macroscopic models. Construction and Buildings Materials; 23,1935-46. http://dx.doi.org/10.1016/j.conbuildmat.2008.09.004

British Standards. (2005). Code of practice for the use of masonry (Standard No. BS-5628). London, UK: British Standards Institution.

Commission Générale de Normalisation du Bâtiment. (1990). Documents Techniques Unifiés. DTU 20. Maçonnerie.

Cubel, F., Vercher, J., Mas, A., Gil, E. (2012). Design and construction recommendations for brick enclosures with continuous air cavity. Construction and Building Materials, 36, 151-164. http://dx.doi.org/10.1016/j.conbuildmat.2012.04.128

Da Silva, R., Mendes, J.A.R. (2007). Defects of non-loadbearing masonry due to partial basal supports. Construction and Building Materials, 21, 19771990. http://dx.doi.org/10.1016/j.conbuildmat.2006.05.028

Del Coz, J.J., Lozano, A., Adam, J.M., Martín, A. (2011). Non-linear hygrothermal failure analysis of an external clay brick wall by FEM - A case study. Construction and Building Materials, 25, 4454-4464. http://dx.doi.org/10.1016/j.conbuildmat.2010.12.039

Del Río, C. (2008). Sistema Structura para fachadas de ladrillo cara vista. Conarquitectura, 25, 81-91.

Dilrukshi, K., Dias, W., Rajapakse, R. (2010). Numerical modelling of cracks in masonry walls due to thermal movements in overlying slab. Engineering Structures, 32, (5),1411-1422. http://dx.doi.org/10.1016/j.engstruct.2010.01.019

Dudas, A., Terjek, A. (2015) Efficiency assessment of posterior waterproofing systems of renovated porous limestone masonry work. Tehnicki vjesniktechnical gazette, 22(5), 1225-1236. http://dx.doi.org/10.17559/TV-20140715083036

European Committee for Standardization. (1992). Eurocode n. 6, Common Unified Rules for Masonry Structures, Report EUR 9888.

Gordejuela, I. (2003). Determinación de la expansión por humedad en los productos cerámicos de uso estructural. PhD Thesis. Departamento de Estructuras, Universidad Politécnica de Madrid, Spain.

Gutiérrez, J., Oteiza, I., Monjó, J., Rey, J. (2008, May 22-24). Estudio del comportamiento mecánico de los muros no portantes de fábrica de ladrillo en fachadas. Paper presented at the II Jornadas de Investigación en Construcción, Instituto de Ciencias de la Construcción Eduardo Torroja del Consejo Superior de Investigaciones Científicas. Madrid: Instituto de Ciencias de la Construcción Eduardo Torroja del Consejo Superior de Investigaciones Científicas.

Hamid, A.A., Wallentén, P. (2017). Hygrothermal assessment of internally added thermal insulation on external brick walls in Swedish multifamily buildings. Building and Environment 123, 351e362. http://dx.doi.org/10.1016/j.buildenv.2017.05.019

López, J., Oller, S., Oñate, E. (1998). Cálculo del Comportamiento de la Mampostería Mediante Elementos Finitos. Barcelona: CIMNE.

Lourenço, P.B. (1996). Computational Strategies for Masonry Structures (Doctoral dissertation). Retrieved from http://www.hms.civil.uminho.pt/arq/fich/1996_PhD_PBLourenco.pdf.

Martins, A., Vasconcelos, G., Campos Costa, A. (2017). Brick masonry veneer walls: An overview. Journal of Building Engineering 9, $29-41$. https://doi.org/10.1016/j.jobe.2016.11.005

Mas, A., Galvañ, V., Gil, E. (2009). Environmental conditions in the deterioration of brick façades. American Society of Civil Engineers, 23, $144-150$. http://dx.doi.org/10.1061/(ASCE)CF.1943-5509.0000001

Ministerio de Fomento. (2006). Código Técnico de la Edificación. Madrid. Website accessed: 2017-11-30. Available online at: https://www.codigotecnico.org

Page, A.W. (1978). Finite element model for masonry. Journal of the Structural Division, 104, 1267-1285.

Paricio, I. (1995). La fachada ventilada de ladrillo caravista. Nueva Arquitectura, 2, 37-70.

Peña, A., Calavera, J., Llorens, M. (2011). Recommendations for the basement wall analysis, subjected to vertical loads originated by the facade pillars. Revista de la Construcción, 10, 122-141. http://dx.doi.org/10.4067/S0718-915X2011000200011

Silva, L.C., Lourenço, P.B., Milani, G. (2017) Nonlinear Discrete Homogenized Model for Out-of-Plane Loaded Masonry Walls. Journal of Structural Engineering, 143(9),04017099. http://ascelibrary.org/doi/10.1061/\%28ASCE\%29ST.1943-541X.0001831

Vercher, J. (2013). Seguridad residual en los forjados con corrosión severa. PhD Thesis. Departamento de Construcciones Arquitectónicas, Universitat Politècnica de València, Spain. Website accessed: 2017-11-30. Available online at: http://hdl.handle.net/10251/27705

Vercher, J., Gil, E., Mas, A., Lerma, C. (2015). Diagnosis and intervention criteria in slabs damaged by severe corrosion of prestressed joists. Journal of Performance of Constructed Facilities 29(1), 04014040. http://dx.doi.org/10.1061/(ASCE)CF.1943-5509.0000515

Zhu, K. Zhu, E. Yang, E. (2011). Finite element Analysis of Reinforced Brick Wall with Opening Hole. Advanced Material Research, $243-249,5506-5511$. http://dx.doi.org/10.4028/www.scientific.net/AMR.243-249.5506

Zuccarello, FA., Milani, G., Olivito, RS., Tralli, A. (2009). A numerical and experimental analysis of unbonded brickwork panels laterally loaded. Construction and Building Materials, 23, 2093-2106. http://dx.doi.org/10.1016/j.conbuildmat.2008.08.031 